\title{
IMPLEMENTASI TOLERANSI BERAGAMA DI PONDOK PESANTREN \\ (Studi Kasus di Pondok Pesantren Universal Bandung)
}

\author{
Irfan Setia Permana W \\ Politeknik TEDC, Indonesia \\ setiairfanpermana@gmail.com
}

\begin{abstract}
The symptoms of religious intolerance in Indonesia began to undermine diversity in Indonesia. The most influential factor in encouraging the occurrence of these symptoms is education. In this case, education that is Islamic in mind is a pesantren. Pesantren is an educational institution that has its own perspective and style of thinking about tolerance. This study aims to determine the constructs of thought and the implementation of religious tolerance implemented in education and activities carried out at Universal Islamic Boarding Schools.

This study uses descriptive qualitative research methods using observation, interview and documentation techniques. The results of the study show that: The construction of thoughts built on religious tolerance is categorized as inclusive thoughts and attitudes in religion, namely thoughts that believe in the existence of truth in other religious beliefs. The foundation of the thought construction is tasamuh, which is a moderate style of Islamic understanding. The concept of religious tolerance is implemented in the policies of Universal Islamic boarding schools through a curriculum of educational activities that reflects education with a multiculturalism-pluralism pattern. This education includes conflict resolution education, Human Rights (HAM), pesantren education for peace. Regarding activities that reflect multiculturalism-pluralism education, namely muhadlarah, pesantren for peace seminars, and cross-cultural discussions with various universities without favoritism.
\end{abstract}

Keywords: tolerance; boarding school; pluralism; multiculturalism

\begin{abstract}
Abstrak
Gejala intoleransi bernuansa agama di Indonesia mulai menggerogoti kebhinekaan di Indonesia. Faktor yang sangat berpengaruh dalam mendorong terjadinya gejala tersebut adalah pendidikan. Dalam hal ini pendidikan yang berwawasan Islam adalah pesantren. Pesantren merupakan institusi pendidikan yang memiliki cara pandang dan corak pemikiran tersendiri tentang toleransi. Penelitian ini bertujuan untuk mengetahui konstruk pemikiran dan implementasi toleransi beragama yang diimplementasikan dalam pendidikan dan kegiatan yang dilaksanakan di Pondok Pesantren Universal.

Penelitian ini menggunakan metode penelitian deskriptif kualitatif dengan menggunakan teknik observasi, wawancara dan dokumentasi. Hasil penelitian menunjukkan bahwa: Konstruksi pemikiran yang dibangun mengenai toleransi beragama dikategorikan sebagai pemikiran dan sikap inklusif dalam beragama, yaitu pemikiran yang mempercayai adanya kebenaran dalam kepercayaan agama lain. Landasan konstruksi pemikiran tersebut adalah tasamuh yaitu corak pemahaman keislaman yang moderat. Konsep toleransi beragama ini terimplementasikan dalam kebijakan pondok pesantren Universal melalui kurikulum kegiatan pendidikan yang
\end{abstract}


merefleksikan pendidikan yang bercorak multikulturalisme-pluralisme. Pendidikan ini meliputi pendidikan resolusi konflik, Human Right (HAM), pendidikan pesantren for peace. Mengenai kegiatan-kegiatan yang merefleksikan pendidikan multikultularisme-pluralisme yaitu muhadlarah, seminar pesantren for peace, dan diskusi lintas budaya dengan berbagai Universitas tanpa pilih kasih.

Kata kunci: Toleransi; pesantren; pluralisme; multikulturalisme

\section{PENDAHULUAN}

Indonesia sebagai negara bangsa (nation state) merupakan hasil dari perjuangan para pendiri bangsa dan bentuk kesepakatan final, dimana keberadaannya sebagai bentuk pengakuan terhadap realitas kemajemukkan sebagaimana yang tertera dalam lambang Bhineka Tunggal Ika (Titik Suwariyati, 2003). Kemajemukan telah melahirkan perpaduan yang indah dalam berbagai bentuk mozaik budaya. Berbagai suku, agama, adat istiadat dan budaya yang hidup secara harmoni dan memiliki ruang negosiasi yang tinggi dalam kehidupan sehari-hari. Kemajemukan juga sebagai modal besar dalam membangun kehidupan yang penuh dengan khazanah kehidupan. Masingmasing bisa saling mengisi dan memperkaya perspektif kehidupan yang bermanfaat untuk meningkatkan kualitas kehidupan khalayak luas.

Harapan kehidupan tersebut bisa tercipta jika pluralitas yang ada dikelola secara baik. Mengelola pluralitas dalam realitas kehidupan ini ternyata tidaklah mudah. Ada berbagai hambatan dan tantangan yang harus dihadapi. Kegagalan dalam mengelola pluralitas bisa menjadi penyebab timbulnya berbagai macam konflik, bahkan menjadi awal konflik yang berkepanjangan.

Mengelola pluralitas tak semudah membalikan telapak tangan. Ide, gagasan, pemikiran dan strategi yang memungkinkan terwujudnya kehidupan yang harmonis harus terusmenerus diusahakan. Di tengah realitas semakin menguatnya gejala-intoleransi dan radikalisasi dalam kehidupan keagamaan, kontribusi dalam bentuk apapun dalam rangka mengelola keragaman sangat diperlukan (Amin Abdullah, 2014).

Dewasa ini, gejala intoleransi yang bernuansa agama di Indonesia mulai menggerogoti kebhinekaan. Sehingga menimbulkan perhatian yang serius dari berbagai kalangan. Hal ini juga tentu menjadi bahan renungan dan perhatian bersama. Sebab apabila sikap intoleran atas nama agama ini dibiarkan tumbuh subur, maka hal ini akan mengancam kerukunan umat beragama.

Tumbuh suburnya gejala intoleransi yang bernuansa agama tidak akan lepas dari faktor-faktor yang melatarbelakanginya, salah-satu faktor yang tidak kalah berpengaruh dalam mendorong terjadinya sikap intoleransi atas nama agama di Indonesia adalah pendidikan. Pendidikan inilah yang membentuk karakter dan mampu mendorong seseorang melakukan segala tindakan, sehingga lembaga pendidikan apa pun jenisnya memiliki tugas besar untuk menghadapi persoalan ini. Terlebih lembaga pendidikan keagamaan.

Dalam konteks keindonesiaan, diskursus intoleransi agama Islam dikaitkan dengan lembaga pendidikan 
tradisional, yakni pesantren. Pesantren merupakan salah satu bentuk pendidikan keagamaan yang mendapatkan perhatian khusus di Indonesia, lebih-lebih setelah terjadinya beberapa tindakan radikal yang mengatasnamakan agama. Sebenarnya hal ini menjadi tidak pas jika dikaitkan dengan sejarah lahirnya pondok pesantren yang justru bertujuan untuk melahirkan alim ulama yang berpengetahuan luas dalam agama (tafaqquh fiddin). Hal ini karena pesantren tidak hanya mengajarkan semua ilmu pengetahuan agama dan hukum-hukum Islam saja, akan tetapi memiliki andil yang besar dalam mendidik karakter manusia dalam berperilaku dan bersikap kepada sesama manusia bahkan dengan alam sekalipun.

Sejak awal kemunculannya, pesantren merupakan institusi yang moderat dan akomodatif, juga memiliki cara pandang dan corak pemikiran tersendiri tentang radikalisme. Pesantren sebagai lembaga pendidikan yang berbasis ke-Islaman yang khas Indonesia telah megajarkan kearifan lokal dan menyebarkan budaya damai. Konsep tawassut, tasamuh, tawazun, dan i'tidal yang telah diajarkan para kiai di dunia pesantren menjadi bukti nyata, bahwa pesantren merupakan institusi yang menyemaikan nilai-nilai perdamaian dan anti terhadap radikalisme.

Terciptanya perdamaian dan toleransi antar umat beragama menuntut andil dari semua pihak, terutama tokoh-tokoh masyarakat dan tokoh-tokoh agama. Begitupun juga di lingkungan pesantren, figur Kiai menjadi sangat berpengaruh terhadap peserta didiknya (santri), dimana Kiai dijadikan sebagai teladan dalam segala hal, mulai dari perilaku, pernyataan dan himbauan dalam kehidupan mereka. Dengan demikian, figur Kiai sangat berpengaruh signifikan dalam mendidik dan mensosialisasikan pentingnya toleransi beragama dan menanamkan pemahaman yang inklusif sehingga tercerminlah wajah Islam yang rahmatan lil 'alamiin.

\section{KAJIAN TEORITIK}

\section{Sejarah dan Dinamika Kehidupan Pesantren}

Telah banyak sumber yang menjelaskan mengenai asal-usul pesantren, tentang kapan awal mula berdirinya, bagaimana proses berdirinya dan bahkan istilah-istilah yang ada dalam dunia pesantren pun seperti istilah kiai, santri yang unsurnya masih menjadi perdebatan.

Mengenai Sejarah dan latar historis berdirinya pesantren di Indonesa berdasarkan Ensiklopedi Islam terdapat beberapa versi pendapat. Pertama, Pendapat yang menjelaskan bahwa asal mula pesantren berakar pada tradisi Islam sendiri, yaitu tradisi tarekat atau tasawuf. Hal ini karena pesantren memiliki keterkaitan yang erat dengan tempat pendidikan yang khas bagi kaum sufi. Pendapat tersebut berdasarkan pada awal penyebaran Agama Islam di Indonesia yang lebih dikenal dengan kegiatan tarekat yang senantiasa melaksanakan zikir dan wirid tertentu. Pemimpin tarekat ini disebut dengan kiai dalam melaksanakan ibadah tertentu. Selain itu juga, biasanya menyediakan kamarkamar kecil yang letaknya di kiri atau kanan masjid untuk tempat penginapan dan memasak. Sehingga dalam kesehariannya juga diajarkan kitab-kitab agama, yang kemudian aktifitas itu dinamakan pengajian. 
Dalam perkembangannya lembaga pengajian tarekat ini tumbuh dan berkembang menjadi lembaga pendidikan yang disebut pesantren.

Kedua, ada yang berpendapat bahwa pesantren yang tidak asing kita kenal saat ini merupakan pengadopsian sistem pendidikan yang pernah didirikan oleh orang-orang Hindu di Nusantara. Pendapat tersebut berdasar pada terdapatnya fakta bahwa pada masa Pra-Islam di Indonesia telah ditemukan beberapa lembaga pendidikan yang mirip dengan pesantren. Lembaga tersebut digunakan untuk tempat belajar dan mengajarkan ajaran agama Hindu dalam membentuk kader-kader penyebar ajaran Hindu. Terdapat penguatan dari pendapat lain yang menyebutkan bahwa sistem pendidikan sejenis pesanren ini tidak ditemukan di negara-negara Islam, melainkan banyak ditemui di negara yang menganut kepercayaan HinduBudha seperti halnya Myanmar dan Thailand (Ensiklopedi Islam, 1993).

\section{Peran Pesantren dalam Membangun Perdamaian (Peace Building)}

Pesantren sebagai salah satu sistem pendidikan indegenous yang telah berabad-abad berperan membentuk karakter dan watak umat Islam di Indonesia. Pesantren seharusnya memiliki potensi menjadi salah satu basis baik secara diskursif maupun moral-praktis dalam menyemaikan nilai-nilai perdamaian di Indonesia.

Bila ditelusuri lebih jauh, pendidikan pesantren pada awal kemunculannya memiliki basis pendidikan perdamaian yang komperhensif. Sebagaimana dikutip dari Suparno dalam bukunya "Pendidikan Perdamaian" mengemukakan bahwa pendidikan perdamain itu mengacu pada karakteristik perdamaian, yang meliputi: 1) Perdamaian itu bersifat dinamis, 2) perdamaian itu ialah sebuah penyelesaian masalah yang adil tanpa kekerasan, 3) perdamaian itu menunjukkan hasil keseimbangan dalam melakukan interaksi sosial, sehingga masyarakat hidup dengan harmoni, 4) perdamaian itu ramah (baik) untuk masyarakat, 5) bila kekerasan merajalela, tentu perdamaian tidak akan tercipta, 6) bertujuan untuk menciptakan keseimbangan dalam dinamika interaksi sosial, perdamaian haruslah berpijak diatas keadilan dan kebebasan (justice and liberty), 7) bila keadilan dihiraukan dan kebebasan dilumpuhkan, maka perdamaian tidak akan tercipta (Suparno dalam Eneng Muslihah, 2014).

$$
\text { Ada sikap yang harus }
$$
dikembangkan dalam sistem pendidikan di pesantren, dimana pesantren sudah seharusnya mendidik umatnya melalui sikap-sikap dan pemikiran yang moderat. Dewasa ini, pesantren dituntut untuk menerapkan model pendidikan yang mengkonstekstualisasikan materimateri khas pesantren dengan isu-isu yang up to date. Materi keislaman yang biasanya hanya berkutat pada kajian kitab turats (kitab-kitab klasik), sekarang ini haruslah mulai nampak di terjemahkan lebih membumi dengan mengintegrasikan terhadap isu-isu kemanusiaan laiknya hak asasi manusia, gender, human traficking, global warming, ekologi, kemajuan teknologi, serta dinamika persoalan humanitas lainnya (Hafidz Ghazali dalam Eneng Muslihah, 2014).

Zamroni sebagai mana dikutip oleh Muslihah bahwa bentuk pesantren 
dalam pendidikan perdamaian harus mengimplementasikan sikap-sikap berikut ini: 1) membangun, menegakkan dan memperbaiki hubungan di semua lapisan masyarakat dan interaksinya, 2) mengembangkan pendekatanpendekatan yang bersifat positif untuk menyelesaikan konflik, dimulai dari konflik yang bersifat personal maupun interpersonal, 3) menciptakan lingkungan yang kondusif baik secara fisik maupun secara emosional, 4) membangun lingkungan yang aman sentosa secara berkelanjutan dan melindunginya dari adanya eksploitasi dan perang (Eneng Muslihah).

Dengan demikian, dapat dipahami bahwa core daripada model pendidikan tersebut adalah adanya keseimbangan antara pembelajaran hukum Islam dengan legal-formal, pendidikan yang responsif dengan kondisi dan keadaan psikologis masyarakat, pembinaan akhlak atau tasawuf yang dialektis dengan normanorma masyarakat serta penanaman nilai-nilai humanitas dan HAM. Jika keempat model pendidikan itu bersinergi dengan baik, maka pondok pesantren akan melahirkan peneruspenerus Muslim yang moderat.

Pendidikan perdamaian adalah sebuah upaya yang harus dilakukan demi terwujudnya nilai-nilai, sikap atau perilaku, dan tata cara hidup yang mendukung terciptanya budaya damai. Asama mengemukakan bahwa pendidikan perdamaian bertujuan untuk menumbuhkan kesadaran dan pemahaman mengenai akar konflik, kekerasan dan ketidakdamaian dalam lingkup yang bersifat personal, interpersonal, komunitas/kelompok, nasional, regional dan internasional (Saefudin Asma, 2009).
Hal ini juga menjadi perhatian Abd. Rahman Assegaf, menurutnya lembaga pendidikan Islam, termasuk didalamnya pesantren, yang bernuansa HAM merupakan upaya dalam mencegah dan menangani konflik dan kekerasan (Abdurrahman Assegaf, 2004). Dalam Deklarasi HAM 1948 yang kemudian diislamisasikan dalam Deklarasi Kairo 1981, disana terdapat butir-butir HAM yang didalamnya terdapat hak hidup (right to life), hak merdeka (right to freedom), hak memperoleh perlakuan yang sama tanpa diskriminasi (right to equity and prohibition against impermissible discrimination), hak mendapat keadilan (right to justice), hak untuk tidak diperlakukan secara semena-mena (right to fair trail), hak memperoleh perlindungan terhadap penyimpangan kekuasaan (right to protection against abuse of power), hak memperoleh perlindungan terhadap siksaan (right of protecion against torture), hak minoritas (right to minority), dan lain sebagainya. Hal ini perlu kiranya untuk diinternalisasikan melalui proses pendidikan. Hal ini juga sejalan dengan tujuan ditetapkannya syariat (maqashid al-Syari'ah).

Pesantren sebagai basis pendidikan yang asli Indonesia, sebagaimana dalam latar historisnya telah ikut andil dan berhasil menegakkan kemerdekaan Indonesia. Sudah seharusnya, di masa sekarang ini turut andil dalam melaksanakan tugas-tugas perdamaian demi terciptanya relasi-relasi harmoni antar sesama manusia yang menghuni wilayah Indonesia.

Dari berbagai landasan naqliyah tersebut, dapatlah dijelaskan bahwasannya bangunan sikap toleransi dapat diupayakan oleh individu yang 
ada, guna mewujudkan masyarakat yang toleran. Ketika kondisi dan situasi toleransi telah dapat terealisasi, maka roda kehidupan umat manusia khususnya bidang agama, akan berjalan sebagaimana mestinya, seiring sejalan tanpa dijumpai "penodaanpenodaan" harkat dan martabat manusia seutuhnya. Harapan dari konstruksi masyarakat yang seperti ini bisa dimulai dari masing-masing individu dari masyarakat tanpa menunggu komando dari pimpinan masyarakat maupun agama.

Toleransi merupakan implikasi dari sebuah keberagaman manusia bahkan dari eksistensi agama. Adanya keberagaman akan menghasilkan sebuah ungkapan yang muncul dari pemahaman seseorang terhadap dirinya dan orang lain, bahwa ternyata harus disadari akan adanya orang lain berikut hal-hal yang melekat padanya. Ungkapan tersebut akan bisa terlaksana manakala seseorang sudah dihadapkan pada realitas orang lain dari eksistensinya. Namun ketika seseorang belum berbenturan dengan "yang lain" tersebut, dia akan mengalami "peng-aku-an" akan eksistensi dirinya sendiri dengan menafikan yang lainnya.

Islam telah mengajarkan kepada umat manusia akan adanya hubungan pribadinya dengan Tuhan (sering disebut dengan hablum minallah) dan juga hubungan pribadinya dengan sesama manusia (hablum minannaas). Islam menjadikan hubungan bermasyarakat merupakan sebuah keharusan bagi penganutnya dalam kehidupannya sehari-hari. Keharmonisan manusia dengan Tuhan nantinya akan terealisasi dalam kehidupan bermasyarakat. Dengan arti yang lain bahwa kesalehan sosial atau keharmonisan dengan masyarakat merupakan wujud komitmen dan dedikasinya akan kesalehan individualnya dengan Tuhan. Banyak ayat dari surat-surat Al-Qur'an menunjukkan adanya penyebutan iman dan amal secara bersambung. Hubungan ini sering diistilahkan dengan uhkhuwwah islamiyah. ${ }^{1}$

Dalam penerapan konsep dan wawasan ukhuwwah, dapat dilakukan melalui berbagai cara, melalui bermacam lembaga serta sarana, antara lain: pertama, persaudaraan Islam (ukhuwwah islamiyah) seyogyanya dimulai dari linkungan yang paling kecil (keluarga), kelompok atau warga suatu jam'iyah, kemudian dikembangkan dalam lingkungan yang lebih luas (antar jam'iyah aliran dan bangsa); Kedua, perlu adanya keteladanan yang baik (uswah hasanah) dari pemimpin ummat, diperlukan keteladanan dari para pengurus organisasi untuk menampilkan sikap ukhuwwah yang dapat dijadikan contoh oleh warganya dan ummat Islam pada umumnya, baik dalam kehidupan pribadi maupun dalam kehidupan fungsionalnya sebagai warga masyarakat.

Ketiga, mengembangkan perluasan cakrawala berpikir dalam masalah keagamaan maupun kemasyarakatan, dalam rangka lebih meningkatkan saling pengertian dan saling memahami wawasan pihak lain, dan mengembangkan sikap keterbukaan dalam menghadapi masalah-masalah sosial; Keempat, terbentuknya lembaga-lembaga atau

\footnotetext{
1 Sidang Komisi IV Muktamar ke-28 Nahdlatul Ulama, Pesan-pesan Mengenai Masalah-Masalah Masyarakat, Bangsa, dan Negara; Ukhuwah Islamiyah dan Persatuan Nasional, Yogyakarta, 29 Rabi'ul Akhir 1410 H. Diambil dari: http://www.nu.or.id/page.php?lang=id\&menu=news _view\&news_id=11081.
} 
pranata-pranata yang dapat menumbuhkan kerukunan, persatuan dan solidaritas warga dan ummat, seperti koperasi, badan-badan kontak, konsultasi dan lain sebagainya, sesuai dengan perkembangan dan kebutuhan ummat; Kelima, mendayagunakan semua lembaga dan sarana yang sudah tersedia, baik yang diadakan oleh pemerintah maupun oleh swadaya masyarakat sendiri, seprti MUI, pesantren, sekolah dan perguruan tinggi, sebagai sarana pengembangan persaudaraan Islam dan persatuan nasional.

Keenam, mendayagunakan pesantren dan lembaga-lembaga pendidikan lainnya, agar lebih berperan dalam pengembangan wawasan ukhuwwah, baik melalui program kurikuler, kokurikuler maupun ekstra-kurikuler. Ketujuh, menciptakan suatu mekanisme yang baik dan efektif dalam kehidupan masyarakat dengan mampu berperan dalam menyelesaikan masalah, jika terjadi perbedaan pendapat atau dalam mengatasi perbedaan pendapat dengan pihak-pihak lain.

\section{METODE}

Penelitian ini merupakan penelitian lapangan yang bersifat deskriptif, dengan menggunakan faktafakta yang objektif. Sumber data dalam penelitian ini meliputi data primer dan data sekunder, yaitu: Data primer, adalah data yang diperoleh dari hasil wawancara dengan pengasuh, para pengajar dan para santri Pondok Pesantren Universal Bandung. Data sekunder, yaitu literatur yang berkaitan dengan penelitian berupa bahan pustaka, baik berupa buku, jurnal, atau penelitian lain yang memiliki keterkaitan dengan penelitian.

Data-data penelitian ini dikumpulkan dengan teknik observasi partisipan yang merupakan keterlibatan langsung peneliti di lokasi penelitian. Wawancara yang digunakan adalah wawancara yang dilakukan secara informal. Wawancara ini juga digunakan bersamaan dengan metode observasi partisipasi. Studi kepustakaan atau dokumentasi dilakukan untuk melengkapi dan menguatkan data yang diperoleh baik dari hasil wawancara maupun observasi. Disamping itu, untuk kepentingan yang bersifat teoritis, guna memperoleh data yang valid dan masukan atas masalah penelitian terkait implementasi toleransi beragama.

Setelah data dikumpulkan, kemudian data diuji keabsahannya dengan teknik triangulasi dataSetelah data terkumpul dengan baik, kemudian diedit dan dipilah. Data kualitatif yang dikumpulkan dengan pengamatan berpartisipasi, wawancara mendalam dan studi dokumentasi dianalisis dengan model interaktif.

\section{HASIL DAN PEMBAHASAN}

Konstruksi Pemikiran Toleransi Beragama di Pondok Pesantren Universal Bandung

Konsep toleransi beragama yang dibangun di Pondok Pesantren Universal ini merupakan toleransi yang berlandaskan nilai-nilai ukhuwwah. Toleransi ini didasari sikap tasamuh, ta'awun. Hal ini senada dengan konsep toleransi dalam Islam yang mengedepankan nilai-nilai ukhuwwah (persaudaraan). Dalam aplikasinya, ukhuwwah tersebut menuntut adanya sikap-sikap dasar yang akan mempengaruhi realitas kehidupan 
sosial. Sikap-sikap tersebut diantaranya: saling mengenal (ta'aruf), saling menolong (ta'awun), saling mendukung (tadlamum), dan saling menyayangi (tarahum).

Toleransi merupakan sikap saling menghargai dengan penuh kesadaran dan ketulusan terhadap realitas kemajemukkan, namun tetap mengedepankan sikap ta'awwun yaitu dengan saling tolong menolong terhadap sesama. Toleransi berasal dari tiga aspek yang sering disampaikan dalam kajian-kajian di Pondok Pesantren Universal yaitu inklusif, empatik, dan toleran yang dikaitkan dengan konsep tasamuh, dan taawun. Toleran tetap menjunjung kebersamaan dan harus didasari pada sikap empatik. Toleran saja tanpa didasari oleh empatik yang tulus itu tidak tasamuh. Tasamuh itu dari lubuk hati yang paling dalam untuk menghormati perbedaan dengan sebuah kesadaran yang disebut dengan kesadaran etis fungsional universal (kesadaran dalam memposisikan diri). Konsep tasamuh lebih tinggi dari sikap toleran. Ketika kita bertoleransi, itu berarti didasari oleh kedalaman hati, maka tidak akan mudah terprovokasi.

Toleransi berarti merupakan sebuah kesadaran sikap, bagaimana seharusnya kita memposisikan diri dalam menghadapi keragaman atau perbedaan dalam beragama. Dalam menyikapi berbagai realitas kemajemukkan tersebut tentunya harus didasari dengan ketulusan, empatik atau keterpanggilan jiwa yang tidak terintervensi oleh pihak luar. Jika dikaitkan dengan teori toleransi, hal ini senada dengan konsep toleransi yang dikemukakan oleh Daud Ali penulis buku pendidikan Islam, bahwa sikap toleransi itu harus didasari dengan kelapangan dada yang bisa diartikan sebagai proses bertoleransi dengan tulus tanpa pamrih.

Pandangan dan konsep toleransi beragama harus mengarah pada kemanusiaan secara universal dan mencerminkan Islam yang rahmatan lil 'alamiin. Hal ini menjadi konsep yang mendasari konsep toleransi di kalangan ustadz (tenaga pendidik). Toleransi beragama sesuai dengan terbangunnya Islam itu sendiri, yaitu yang rahmatan lil alamiin bukan rahmatan lilmuslimin dalam artian Islam itu menebar kasih sayang untuk makhluk seluruh alam, tidak hanya umat Islam. Akan tetapi seluruh umat manusia di dunia bahkan hewan, tumbuhan, dan sebagainya pun berkasih sayang. Dengan memiliki dasar tersebut, kita bisa menjadi pribadi yang toleran terhadap umat beragama lain. Lebih tepatnya toleransi itu sikap saling menghormati, menghargai, saling bergandengan tangan dengan sadar, bahwa perbedaan bukan untuk diperdebatkan namun disatukan dalam misi kemanusiaan.

Toleransi adalah sebuah sikap saling menghargai dengan memprioritaskan kebenaran agama sendiri yang lebih utama. Namun tidak serta-merta memandang keyakinan, pendapat, maupun pemikiran orang lain salah. Konsep ini mengacu pada corak pemikiran yang inklusifistik. Toleransi harus berdasar pada prinsip perdamaian. Sikap toleransi yang mengarah pada pembangunan perdamaian dan persatuan ini ditunjukkan secara interaksi dalam hubungan antar umat beragama. Jikalau kita mengucapkan selamat dalam hubungan antar manusia, ikut suasana bahagia dalam suka cita agama lain merupakan hal yang manusiawi. Jadi, tidak bisa dihukumi menjadi kafir 
atau keberagamaannya terganggu. Apalagi jika yakin bahwa hidayah, pertolongan itu Allah yang mengatur. Meskipun ada yazidu, wa yanqusu. Yazidu juga bisa jadi karena Dzat yang Maha membolak-balikkan hati. disisi lain dengan bantuan bimbingan Allah dan ada usaha manusia untuk mencapai keistiqomahan di titik itu.

Dalam mengembangkan toleransi diperlukan sikap yang moderat, sebagaimana Hasyim Muzadi mengatakan, bahwa untuk menangkal bahaya radikalisme, terorisme, konflik internal dan krisis multidimensional perlu diperkuat watak Islam moderat di kalangan dunia Islam (Hasyim Muzadi dalam M. Sidi Ritaudin, 2017). Konsep Islam moderat juga menjadi latar belakang landasan Pondok Pesantren Universal dalam pengembangan sikap beragamanya. Dimana Islam moderat (wasathiyyah) menjadi sikap yang terbaik. Untuk melahirkan sikap moderat diperlukan proses kehidupan yang terbiasa hidup berbaur dengan orang-orang yang berbeda, baik itu dalam segi kepercayaan, pola pikir, maupun corak pemahaman. Sehingga sikap-sikap moderat itu akan terlatih dan terasah sebagai bentuk penghormatan diri terhadap fitrah realitas kemajemukkan tersebut.

Dalam relasi hubungan antar manusia, keimanan itu dalam banyak kasus teman-teman yang sekolahnya di luar negeri keberagamaannya lebih baik, tidak terganggu. Bahkan penilaian bagus atau tidak bagusnya keberagamaan seseorang, orang yang berinteraksi dengan kelompok atau agama yang berbeda itu lebih moderat dan toleran. Tentu sikap moderat itu merupakan sikap terbaik dalam banyak pandangan. Sebagaimana kutub negatif dan kutub positif, jika terlalu ekstrim kanan jelek, terlalu ekstrim kiri juga jelek. Terlalu kikir tidak boleh, terlalu royal pun tidak boleh, sikap tengahtengah itu yang terbaik. Kaitannya dengan keberagamaan ada yang dipahami sebagai islam wasathiyyah itu yang terbaik. Jika itu ukurannya, yang dipahami dan disaksikan sekarang, orang yang punya pandangan islam wasathiyyah itu mereka yang dalam proses kehidupannya berinteraksi dengan orang-orang yang berbeda agama. Mereka yang toleran terhadap perbedaan akan melahirkan sikap wasathiyyah.

Jika dikaitkan dengan pandangan Said Agil Munawar dalam Fiqih Hubungan Antar Agama. Menurutnya, bahwa sikap toleransi terbagi kedalam dua macam yaitu toleransi statis dan dinamis. Toleransi statis merupakan jenis toleransi yang melahirkan suatu komitmen bersama, hanya saja bersifat idealis/teoritis. Sementara toleransi dinamis merupakan toleransi aktif yang melahirkan kerja sama untuk tujuan bersama. Dengan demikian, hidup berbaur yang telah menjadi habit atau kebiasaan akan melahirkan sikap toleransi aktif yang menjadi sebuah refleksi dari kebersamaan umat beragama, akan melahirkan sikap toleransi yang didasari sebuah komitmen yang mengantarkan pada tujuan bersama.

Ketika dihadapkan dengan sikapsikap intoleran, eksklusifistik, dan bahkan radikal hal ini timbul dikarenakan sempitnya cakrawala berfikir dan adanya fanatisme yang berlebihan. Dalam hal ini Pondok Pesantren Universal menegaskan, sikap-sikap intoleran, radikalis, dan eksklusifistik berasal dari pemahaman yang selalu berorientasi pada figh 
oriented yang hanya mempersoalkan masalah halal/haram, kafir, bid'ah, cenderung hitam/putih, dan tekstualis.

Jika orang terjebak dalam sikapsikap teks, literalis, atau hitam-putih memiliki

kecenderungan mengekspresikan keagamaannya secara keras, hitam-putih, beberapa hal malah semacam arogansi kebenaran, prioritas keberagamaan yang gagah dan agung, tetapi dalam memperjuangkannya keagungannya itu, tidak cantik. Dalam istilah teologi ada istilah yang dinamakan jalal dan jamal. Jalal itu gagah perkasa, namun jika keagungannya diekspresikan dengan sikap arogansi maka itu menjadi tidak indah. Padahal dalam alQuran bilhikmah wal mau'idzatil hasanah. Ahsan itu terbaik, bukan hanya baik saja. Ihsan itulah puncaknya Islam yang merupakan mental universal yang tidak ada iming-iming atau amang-amang.

Prinsip diatas memberikan gambaran bahwa dalam konsep toleransi bergama menurut Pondok Pesantren Universal adalah sikap saling menghargai terhadap perbedaan dalam hal keyakinan, pemikiran, pandangan, atau pendapat. Dalam bertoleransi diperlukan sikap inklusif, empatik, dan saling menghargai untuk membangun sikap yang moderat dan terciptanya bagunan perdamaian.

Dalam ruang lingkup toleransi itu terdapat tiga arah, sebagaimana dikemukakan oleh Dr. Mukti Ali yang telah terancang dalam Tri Kerukunan Umat Beragama yang didasarkan pada Surat Keputusan Menteri Agama Republik Indonesia Nomor 70 dan 77 tahun 1978 tentang Tri Kerukunan Hidup Beragama yaitu meliputi: 1) Kerukunan Intern Umat Beragama; 2) Kerukunan Antar Umat Beragama; 3) Kerukunan Antar Pemerintah dengan
Umat Beragama (DEPAG RI, 1997). Jika dilihat dari sudut ini, secara ekstern (antar umat beragama) konsep toleransi beragama yang dibangun di Pondok Pesantren Universal telah mencerminkan sikap-sikap yang memadai dalam toleransi beragama.

Berdasarkan konstruk pemikiran yang dibangun di Pondok Pesantren Universal menunjukkan bentuk toleransi dinamis, dimana secara teoritik memang telah menunjukkan adanya sikap toleran. Namun, secara praktik memang belum terpraktikkan semua. Mengingat, dalam dunia pesantren memang tidak terdapat variasi penganut agama yang berbeda. Namun, jika secara internal keagamaan, dalam kehidupan pesantren memang terdapat corak dan latar belakang keagamaan yang berbeda. Sehingga konsep toleransi ini sudah berjalan secara baik.

\section{Implementasi Toleransi Beragama di Pondok Pesantren Universal}

Dewasa ini, pesantren dituntut untuk menerapkan model pendidikan yang mengkonstekstualisasikan materimateri khas pesantren dengan isu-isu yang up to date. Materi Keislaman yang biasanya hanya berkutat pada kajian kitab turats (kitab-kitab klasik), sekarang ini haruslah nampak diterjemahkan lebih membumi dengan mengintegrasikan terhadap isu-isu kemanusiaan seperti toleransi, gender, ekologi, kemajuan teknologi, human traficking, serta dinamika persoalan humanitas lainnya (Hafiz Ghazali dalam Eneng Muslihah, 2014). Hal tersebut mengarah pada terciptanya bangunan perdamaian, yang terinternalisasi dari pendidikan perdamaian.

Pendidikan perdamaian adalah sebuah upaya yang harus dilakukan 
demi terwujudnya nilai-nilai, sikap atau perilaku, dan tata cara hidup yang mendukung terciptanya budaya damai. Asma mengemukakan bahwa pendidikan perdamaian bertujuan untuk menumbuhkan kesadaran dan pemahaman mengenai akar konflik, kekerasan dan ketidak-damaian dalam lingkup yang bersifat personal, interpersonal, komunitas/kelompok, nasional, regional dan internasional (Saefudin Asma, 2009).

Dalam kaitannya dengan model pendidikan yang berbasis pengembangan materi kekinian tersebut, Pondok Pesantren Universal sejak awal berdirinya melakukan kaderisasi keulamaan dalam tradisi keilmuan yang berorientasi tafaquh fi aldin. Sesuai dengan karakternya yang senantiasa akomodatif dengan perkembangan masyarakat dalam rangka mempertahankan eksistensinya sekaligus menjawab tantangan dan perubahan zaman. Dalam konteks mempersiapkan kader ulama yang akomodatif terhadap segala jenis kemajemukkan dalam masyarakat, pesantren menyiapkan kurikulum pendidikan perdamaian yang lebih kontekstual, selaras dengan tantangan yang dihadapinya.

Dalam penerapan pendidikan perdamaian yang bermuatan nilai toleransi, HAM, dan lain-lain. Melalui normative reeducative strategy Pondok Pesantren melakukan transmisi dan internalisasi nilai-nilai ke-Islaman yang inklusif, damai, dan toleran sehingga terbangun kapasitas perdamaian di kalangan para santri dan masyarakat yang pada gilirannya diharapkan mampu menciptakan bangunan perdamaian yang abadi.

Proses perubahan masyarakat itu ada karena dipaksa atau provokator.
Orang berubah karena ada yang namanya the great man yaitu ada orang besar yang mengkomando. Justru pola pendidikan perdamaian di pesantren itu andragogy, sufistik. Nah disitu ada yang namanya normative reeducative strategy, dimana dalam merubah manusia itu dengan menginstal atau memasukkan dalam dirinya norma, nilai-nilai sufistik, prinsip inklusif, empatik, toleran, pembelajaran orang dewasa. Lalu nilai-nilai itu dimaknai, direfleksikan secara kritis oleh anak didik atau santri melalui edukatif dan reedukatif. Mengapa reedukatif strategi, karena prosesnya tidak sekali jadi. Prosesnya secara terus-menerus, ada namanya habit yang berulangulang. inklusif, empatik, toleran tidak bisa hanya sekedar jargon, kampanye, sekali ketemu, tapi terpola dalam proses edukatif-reedukatif, berulangulang, dicontohkan dalam kegiatan, dan diingatkan terus.

Dalam mengembangkan model pendidikan toleransi beragama yang berwawasan multikulturalismepluralisme. Pondok Pesantren Universal mengembangkannya dalam sebuah rancangan visi dan misinya. Dalam perumusan visi dan misi Pondok Pesantren Universal, terdapat tujuan yaitu untuk menjawab stigma negatif yang dialamatkan kepada Pondok Pesantren. Pondok Pesantren memiliki tanggung jawab besar terhadap maraknya gelombang intoleransi, arogansi radikal yang menjalar dalam kehidupan kampus. Maka Pondok Pesantren Universal hadir sebagai respon dalam menangkal itu semua.

Pondok Pesantren Universal didirikan sebagai respon atas keprihatinan beberapa pihak berkaitan dengan kondisi kampus (Perguruan 
Tinggi) yang selama ini dikenal sebagai tempat persemaian manusia yang memiliki pandangan kritis, open minded, objektif, namun ternyata tidak kebal terhadap pegaruh ideologi radikal. Sehingga, pangkal-pangkal ideologi radikalis ini menyeruak menjadi sikap-sikap yang ekslusifistik, intoleran, dan sel-sel radikal dapat ditemukan dalam skala berbeda di banyak perguruan tinggi di Indonesia termasuk di Kota Bandung.

Dalam pandangan Azyumardi Azra, kecenderungan orang dalam memahami segala sesuatu itu hitam putih khususnya yang berasal dari sekolah menengah non-keagamaan yang sebelumnya tidak banyak mendapatkan materi-materi keagamaan dan keragaman perspektif Islam, semangat keagamaannya semakin tumbuh di kampus-kampus. Terlebih ketika mereka dipertemukan dengan "mentor" dari organisasiorganisasi kemahasiswaan intra maupun ekstra kampus tertentu, semangat dan militansi keagamaannya semakin kuat bahkan cenderung ekstrem.

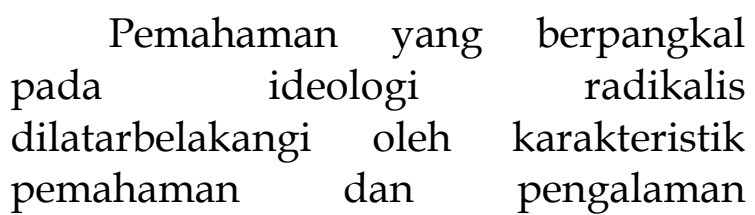
keagamaan di kalangan remaja, khususnya mahasiswa perguruan tinggi. Dengan demikian, menurut Pondok Pesantren Universal ada sikapsikap yang harus dikembangkan sebagai respons daripada keprihatinan tersebut, yaitu dengan pendidikan 'kontra ideologi'. Bagi Pondok Pesantren Universal, idelogi radikal dan pemahaman keagamaan Islam yang sempit, eksklusif, dan intoleran tidak dapat diatasi dengan tindakan represif aparat penegak hukum. Apalagi 'korban' dari propaganda ideologi tersebut adalah para remaja. Berbagai macam serangan ideologi radikal ini harus dihadapi dengan "kontra-ideologi", pendidikan perdamaian dan perspektif keIndonesiaan dan ke-Islaman yang inklusif, empatik, dan toleran.

Pendidikan toleransi dan resolusi konflik pada hakikatnya bersifat holistik berkaitan dengan dimensi ranah kognitif, afektif, dan keterampiran (skill, psikomotorik). Oleh karena itu, pendidikan dan pengajaran di Pondok Pesantren Universal ini didesain dengan menggabungkan teori kritis, metodologi partisipatif, dan pengalaman.

Jika dikaitan dengan teori pendidikan multikulturalisme yang dikembangkan oleh James A. Banks, yang menyebutkan bahwa pendekatan dalam mengintegrasikan pluralisme, toleransi beragama, dan pendidikan perdamaian. Pondok pesantren Universal menggunakan pendekatan kontributif (contribution approach), pendekatan mata pembelajaran tambahan, pendekatan transformatif (transformatif approach) dan pendekatan aksi sosial dimana dilakukan dengan memusatkan perhatian pada pengenalan unsur-unsur keragaman melalui berbagai muatan-muatan pendidikan ke-Islaman yang mengenalkan corak pemikiran kegamaan atau madzhab yang berbeda.

Selain itu, Model pendidikan yang digunakan adalah pendidikan orang dewasa (andragogy), melalui kegiatan pendidikan dan pengajaran dengan menggunakan model pendekatan 'peran', model praxis (aksirefleksi) yang penerapannya dilakukan in-class yaitu berupa bandungan, sorogan, tausiah, diskusi, bahtsul masa'il dan out-class (riset aksi, out bond, field 
study). Model pendidikan di Pondok pesantren Universal tidak saja mengkaji kitab-kitab turats dan klasik, namun di sisi lain mengadopsi beberapa hal baru terkait dengan toleransi, pesantren for peace, maka materi-materi tidak tercermin sematamata pada kitab yang dibaca tetapi juga pada kemasan kegiatan di pesantren, melalui LKMS, diskusi, maupun menghadirkan orang

Hasyim Muzadi mengungkapkan bahwa dalam mengembangkan model pendidikan yang berwawasan toleransi, pondok pesantren harus menjaga keseimbangan antara hukum Islam dengan legal-formal, pendidikan responsif dengan kondisi dan keadaan psikologis masyarakat, pembinaan akhlak atau tasawuf yang dialektis dengan norma-norma masyarakat serta penanaman nilai-nilai HAM. Jika model pendidikan ini bersinergi dengan baik, maka pondok pesantren akan melahirkan penerus-penerus muslim yang moderat.

Dalam kaitannya dengan pandangan tersebut, Pondok pesantren Universal menerapkan model pendidikan yang juga berbasis wawasan toleransi, meskipun seluruh komponen dalam model pendidikan tersebut belum bersinergi secara menyeluruh. Dalam merefleksikan nilai-nilai pendidikan multikulturalisme pluralisme, Pondok pesantren Universal sempat memasukkan materi kitab rohmatul ummah fikhtilafil aimmah dan juga memasukkan muatan-muatan tasawuf. Hal itu dilakukan karena didalamnya terdapat pembelajaran tentang menata hati, akhlak, bukan fiqih semata-mata. Hal ini merupakan suatu proses yang membangun sikap toleran dan kelembutan hati, bahkan termasuk kitab-kitab yang kita baca. Ta'lim bukan kitab syafi'iyyah saja, akan tetapi juga mengadopsi kitab-kitab yang yang lain. Semakin sebuah pesantren mengkaji kitab kuning, maka pesantren tersebut semakin toleran. karena di kitab klasik itu selalu disampaikan qoul-qoul (pendapat) yang berbeda. Maka pesantren Universal mempertahankan mengkaji kitab klasik, seperti safinah, dan taqrib, meskipun itu berasal dari ulama syafi'iyyah tetapi disyarah dari berbagai pendapat, dan itu disampaikan. Dengan demikian, maka mengapa pesantren klasik banyak melahirkan kader ulama yang moderat karena disitu disampaikan berbagai versi pendapat dari ulama yang memiliki corak pemikiran yang berbeda dan santri sudah terbiasa dengan pendapat yang berbeda.

Pendidikan berbasis agama (pesantren) seyogyanya berkiprah dalam mengenalkan problematika keragaman, yang tentu saja mengandung nilai-nilai yang mampu menumbuh-kembangkan sikap-sikap toleransi, inklusif pada generasi muda. Dengan berdasar pada prinsip kurikulum pendidikan agama Islam. Hal tersebut juga tentunya harus mempertimbangkan komponen, bahan, metode, peserta didik, media, lingkungan, dan sumber belajar.

Secara metode pembelajaran, Pondok Pesantren Universal sama halnya dengan pesantren lain pada umumnya. Namun, dalam metode yang digunakan sebagaimana telah dibahas sebelumnya tetap menggunakan aksi-refleksi dimana setiap pengajaran yang berkaitan dengan penanaman pendidikan toleransi ditanamkan melalui metode reeducative, dimana penanaman nilai- 
nilai multikulturalisme-pluralisme ini disampaikan berulang-ulang. Hal ini bertujuan agar santri dapat memahami dan menerapkannya secara continue (berkelanjutan), setelah itu akan menjadi habit, dan kemudianberharap menjadi karakter santri Pondok Pesantren Universal yang inklusif.

\section{KESIMPULAN}

Berdasarkan data hasil penelitian serta pembahasan dan analisis data dalam penelitian ini, dapat disimpulkan bahwa konstruk pemikiran pondok pesantren Universal menunjukkan adanya pembentukan pemikiran untuk memiliki sikap toleransi. Toleransi beragama dalam pandangan Pondok Pesantren Universal adalah sikap keberagamaan yang menerima realitas kemajemukan didasari dengan nilai empatik tanpa adanya intervensi oleh pihak manapun. Mengenai corak pemahaman dalam batasan toleransi beragama, dalam pemahamannya lebih mengarah kepada corak keberagamaan yang inklusifistik.

Hal tersebut dapat dilihat dari pandangan pengasuh Pesantren mengenai batasan bergaul dalam relasi harmonis antar umat beragama harus tetap berjalan, namun setiap manusia memiliki batasan sendiri dalam aqidah masing-masing yang membuat manusia tersebut mempertahankan keyakinannya. Pondok Pesantren Universal memposisikan kebenaran agama Islam sebagai agama yang dianutnya dengan tidak sama sekali mengurangi penghormatannya terhadap agama lain, serta menjadi ganjalan dalam menjalin toleransi beragama dalam kehidupan bermasyarakat.

Pemikiran mengenai toleransi beragama pun diimplementasikan dengan baik dalam kebijakan Pesantren dalam kegiatan pembelajaran dengan dimasukkan dalam kurikulum pembelajaran. Bahkan Pondok Pesantren Universal memiliki semboyan utama Pondok Pesantren yaitu prinsip inklusif, empatik, toleran dengan tetap menyayangi meskipun dalam perbedaan. Selain itu, Pondok Pesantren Universal juga terlibat aktif dalam sejumlah kegiatan yang melibatkan umat lintas agama, seperti dalam kegiatan pesantren for peace, mengikuti sejumlah kegiatan youth camp interfaith, diskusi lintas iman, dan menerima umat agama lain yang live in di Pondok Pesantren. Pondok Pesantren Mahasiswa Universal sudah memiliki upaya dalam membangun pendidikan yang berwawasan toleransi beragama yang bercorak multikulturalisme-pluralisme, akan tetapi memang masih terdapat kekurangan yang harus dikembangkan secara menyeluruh dimana terkait lingkup kehidupan internalnya.

\section{Buku nan Jurnal}

\section{DAFTAR PUSTAKA}

Assegaf, Abdurrahman. 2004. Pendidikan tanpa Kekerasan Tipologi Kondisi, Kasus dan Konsep. Yogyakarta: Tiara Wacana Yogya.

Muslihah, Eneng 2014. "Pesantren dan Pengembangan Pendidikan Perdamaian". Dalam jurnal Studi Keislaman, Volume 1, Nomor 2.

Asma, Saefudin. 2009. "Damai Itu Apa (Sekilas Mengajarkan Perdamaian", dalam Kompasiana. 
DEPAG RI, 1997. Bingkai Teologi Kerukunan Hidup Umat Beragama di Indonesia. Jakarta: Badan Penelitian dan Pengembangan Agama Proyek Peningkatan Kerukunan Umat Beragama di Indonesia.

Dewan Redaksi. 1993. Ensiklopedi Islam. Jakarta: Ichtiar Baru Van Hove.

Ritaudin, Sidi. 2017. Promosi Islam Moderat Menurut KETUM MUI Lampung dan Rektor Universitas UIN Raden Intan Lampung. Jurnal TAPIs Vol. 13 No. 02.

Abdullah, M. Amin. 2014 "The Intersubjective Type of Religiosity: A Contribution (a Fresh Ijtihad) of Indonesian Islamic Studies to a Multicultural Society", Makalah, AICIS XV.

Suwariyati, Titik. 2003. "Konflik-konflik sosial bernuansa agama di berbagai komunitas (Kasus Kerusuhan Sosial di Banjarmasin 1997)". Jakarta: Departemen Agama RI.

\section{Website}

http:// umum.kompasiana.com/2009/06/17/damai-itu-apa-sekilas-pendidikanperdamaian-7205.html).

http://www.nu.or.id/page.php?lang=id\&menu=news_view\&news_id=11081. 